\title{
СЕСКВИТЕРПЕНОИД ОКСИД КАРИОФИЛЛЕНА - СКАФФОЛД ДЛЯ ПОИСКА И СИНТЕЗА ВЕЩЕСТВ С ФАРМАКОЛОГИЧЕСКОЙ АКТИВНОСТЬЮ
}

\author{
Ю.В. Гырдымова, С.А. Рубцова
}

Институт химии ФИЦ Коми НЦ УрО РАН, 167000, Россия, Сыктывкар, ул. Первомайская, 48.

DOI:10.19163/MedChemRussia2021-2021-154Ｅ-mail: gyrdymova-jw@chemi.komisc.ru

Оксид кариофиллена - природный сесквитерпеноид, обладающий широким спектром биологической активности. Интересная и своеобразная структура этого соединения позволяет использовать его как универсальную платформу для поиска и синтеза на его основе широкого спектра продуктов разнообразного строения. Ранее нами была показана перспективность использования оксида кариофиллена в синтезе серосодержащих соединений с антиоксидантными [1], мембранопротекторными [1] и противогриппозными [2] свойствами. В представленной работе из оксида кариофиллена нами были синтезированы кетоны различного строения - кариофилланового, клованового, панасинсанового строения, которые затем были трифторметилированы системой Рупперта-Пракаша с получением F-производных.

Для синтезированных трифторметилированных продуктов была проведена оценка возможной биологической активности по Поройкову с использованием онлайн-ресурса Pass Online http://way2drug.com/passonline/, a также оценка безопасности и эффективности соединений с использованием онлайн-ресурса ADMET http://qsar.chem.msu.ru/admet/.

Работа выполнена при частичной финансовой поддержке РФФИ, грант № 19-03-00951_A.

\section{References}

[1] Yu. V. Gyrdymova, D. V. Sudarikov, O. G. Shevchenko, S. A. Rubtsova, P. A. Slepukhin and A. V. Kutchin, Chem. Biodiversity. 2017, 14, e1700296.

[2] Yu. V. Gyrdymova, E. O. Sinegubova, A. S. Muryleva, V. V. Zarubaev, and S. A. Rubtsova, Chem. Nat. Compd. 2019, Vol. 55, No. 6, 1179-1191. 